\title{
Preliminary Data of Fluvial Geomorphological Evolution and Its Link with Hazards and Human Impact: The Case of Peiros River, North Western Peloponnese, Greece
}

\author{
Georgios Alevizos, Giannis Mpalatsas, Leonidas Stamatopoulos* \\ Department of Geology, University of Patras, Patras, Hellas \\ Email address: \\ geoalevizos@upatras.gr (G. Alevizos),gmpala@otenet.gr (G. Mpalatsas), leonstan@upatras.gr (L. Stamatopoulos) \\ ${ }^{*}$ Corresponding author
}

\section{To cite this article:}

Georgios Alevizos, Giannis Mpalatsas, Leonidas Stamatopoulos. Preliminary Data of Fluvial Geomorphological Evolution and Its Link with Hazards and Human Impact: The Case of Peiros River, North Western Peloponnese, Greece. Earth Sciences. Vol. 7, No. 1, 2018 , pp. 11-16. doi: 10.11648/j.earth.20180701.13

Received: October 17, 2017; Accepted: November 16, 2017; Published: December 20, 2017

\begin{abstract}
River channel dynamics are the result of the complex interaction between natural and human factors, at both local and regional scale. The study of river channel dynamics may be an important way to better understand the mechanisms that rule the functioning of fluvial systems, allowing predictions of its future evolution to be made and appropriate adaptation measures to be taken, remediating the risks related to the fluvial dynamics. The purpose of this study is to present specific aspects concerning the river channel dynamics of Peiros River, NW Peloponnese, Greece and to reveal the role of various control factors. Peiros, the longest river in Achaea, has sources at the NE part of the Erymanthos mountains flowing into Patras gulf. This study traces the various stages of geomorphological evolution of the low part of Peiros's river channel and enables us to study the links between human activity, local tectonics, morphology and fluvial dynamics. The study area belongs to the geotectonic zone of Gavrovo-Tripoli flysch, consisting mainly of medium-bedded fine-grained sandstones and mudstones and influenced by ENE and WNW trending faults aligned with the river flow. The spatial and temporal variability of sediment transport is controlled by various variables, including the natural features of the catchments and human activity. The latter is an important control factor for both the processes of sediment generation, transfer and accumulation and for channel dynamics. At the same time, these processes are responsible on short and long run for the alteration of the river channels, which entail negative environmental consequences. The study revealed restriction of sediment supply, coastal retreat, lateral erosion and migration of the rivers channel that complies with the local tectonics of the area, although major stream offsets are not created. The morphological changes although, are mainly attributed to human intervention factors, such as the construction of a dam and transversal bars that restricted the water flow and consequently the sediment supply. That factor combined with the climate change, had as result to drastically alter the morphology of the area. These morphological changes, except of loss of property and boundary problems, also made the area vulnerable to flush flood events. Structures close to the coast are exposed to more risk because of the measured coast retreat. No remediation measures have been taken, except the installation of rip-rap of limited length and one groin, in an attempt to slow down the coastal retreat and diminish wave action.
\end{abstract}

Keywords: River Dynamics, Fluvial Revolution, Channel Adjustments, Hazards, Human Impact, Peiros River, Peloponnese, Greece

\section{Introduction}

River systems are characterized by a significant diversity of physical conditions which allows them to adapt rapidly, thanks to their high dynamics, to environmental, especially climatic and human-induced influences. Even the slightest of changes in tectonics, human intervention and local climate correspond to fluvial response and adjustment. Consequently, environmental influences on river systems are easily reflected in channel adjustments which are indicative of the state of equilibrium of the river system [1]. Fluvial dynamics react very fast to changes in sediment supply, discharge and human activity [2]. Sediment transport and river channel dynamics 
are the result of this complex interaction between natural and human factors, at both local and regional scale. The study of sediment transport and river channel dynamics may be an important way to better know and understand the mechanisms that rule the functioning of fluvial system, allowing forecasts of its future evolution to be made and appropriate adaptation measures to be taken by society in front of the risks related to the fluvial dynamics and sediment transfer [3]. Peiros, along with its tributaries, is the largest river in Achaea, having its sources on the Northwestern part of Erymanthos mountain (Figure 1a), at an altitude of $2.224 \mathrm{~m}$. It flows into Patraikos Gulf and its main tributary is Parapeiros river. Its hydrogeological basin belongs to the subbasin of Patras [4].

The Patraikos Gulf, were the rivers estuary is located, forms the western end of a major east-west graben system, extending from the Ionian Sea through the Gulf of Corinth to the Aegean Sea. Major geomorphological and geotectonic events as well as human activity, characterise the evolution of this region in the Holocene [5, 6].

The purpose of this study is to trace the various recent stages of geomorphological evolution of the low part of Peiros river channel (Figure 1b), present specific aspects concerning the sediment transport and river channel of the study area, reveal the role of various channel movement and shape control factors and study the links between human activity and fluvial dynamics.

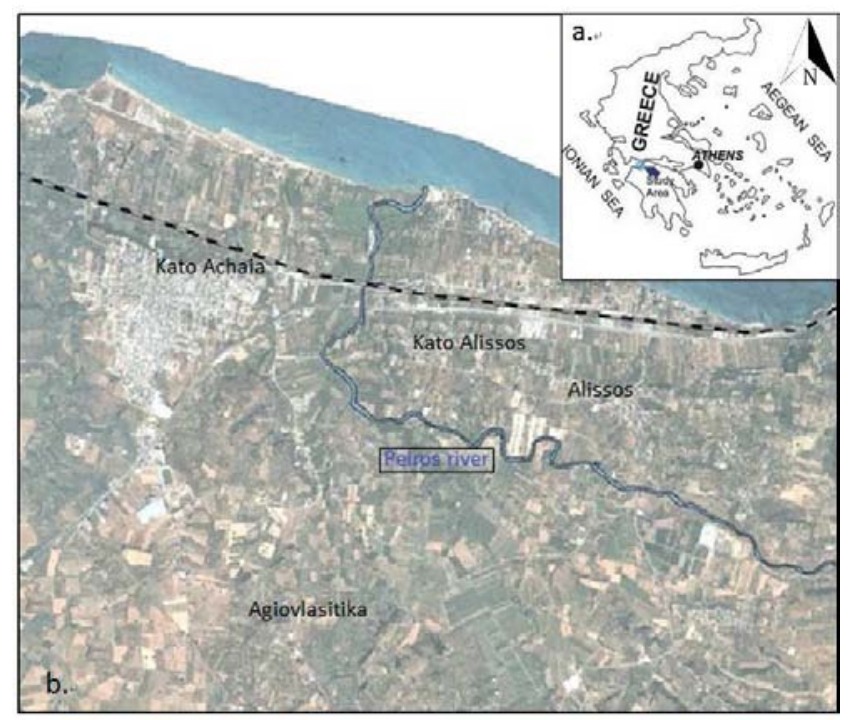

Figure 1. a: View of the study area location marked in blue. $b$ : Peiros river location. Dotted line depicts the old national road.

\section{Methodology}

To study the landscape evolution of the selected area, geological, lithological and hydrological data were compiled and separately analyzed. A geomorphological survey was carried-out, which supplied an overview of the forms and processes, namely the geomorphological dynamics of the investigated area. As concerns geomorphological investigations, in this study, the data were primarily collected by means of bibliographical research, aerial photo interpretation and field survey.

Detailed field investigation of Holocene stratigraphy, coupled with the study of a large number of archaeological sites provided valuable information to better understand the relationships between man and the environment in the study area.

\section{Geographical and Geological Outline}

The Patraikos Gulf lies about $100 \mathrm{~km}$ east from the Hellenic trench, immediately behind the Plio-Quaternary fold belt, which runs parallel to the coast of western Greece [7, 8]. It is a Plio-Quaternary subsidence area of great structural complexity and crosses the Pindos-Gavrovo and Ionian isopic zones of the western Hellenides. The margin of the graben is marked by numerous faults that have been active in the Holocene [9].

The study area lies at the southern coast of Patraikos Gulf, surrounded by pre-Neogene folded rocks of cape Araxos to the west, of Panachaikon mountain to the east and of Skolis mountain to the south. It comprises a thick Upper Tertiary clastic sequence, which overlies unconformably the pre-Neogene basement [7].

Around the southern coast of Patraikos Gulf the yellow fluvial sands are dominant and overlie conformably gray lacustrine mud and gray shallow marine mud. Towards the pre-Neogene margin to the south the yellow fluvial sands change laterally to the alluvial fan deposits. The gray shallow marine mud and the alluvial fan deposits are unconformably overlain by lithofacies of yellow to brown terrestrial fluvial deposits which consist of alternating layers of conglomerates, sand and silt fining upwards [7]. The Peiros river discharge directly into the Gulf of Patras (Figure 2) and its valley was a pre-existing graben. This graben has been following its drainage patterns [10].

The stratigraphic sequence observed at the lower part of the river channel can be interpreted in terms of delta progradation into a basin in which there have been fluctuations in relative sea level while on the higher parts of the river channel, the particles become gradually coarser.

The Late Quaternary evolution is a consequence of interaction between active tectonic subsidence, rapid supply of river sediment, global changes in sea level and human activity. Recently subsided areas of West-Northwest trend as the Preveza Gulf, the Trihonis lake and the Corinthian Gulf are also transected by East-Northeast trending faults. Similarly, seismic faults of the same orientation are mapped after the 1981 Corinth earthquake [7].

The river has developed in a narrow basin that is characterized by faults of various trends but mainly of ENE and WNW trends. The majority of these faults are normal with the exception of a major strike slip fault that cuts the are in Southwest/Northeast direction [11]. The ENE and WNW trending faults are aligned with Peiros river flow.

The group of faults with WNW orientation is younger than the ENE. The younger group doesn't affect the sedimentation taking place during the Pleistocene period, while the older group is characterized as still active [7]. 
A large part of the Peiros's drainage basin is characterized by a slight lifting during the Upper Quaternary period with values of $0.8-1 \mathrm{~mm} / \mathrm{y}$ [12]. It is also characterized by gorges of up to $30 \mathrm{~m}$. deep. These gorges are the cause of the observed strata of Neogene period age and terraces in higher altitudes [10].

The area is situated in a temperate climatic zone (Type Cfa of Koppen's classification). From the pluviometric viewpoint the study area has an annual average rainfall of about $830 \mathrm{~mm}$, with seasonal peaks concentrated in the fall and spring (about $150-190 \mathrm{~mm}$ ), and minimum values in the summer.

The evolution of the hydrological basin of Peiros river is undoubtedly different from the surrounding areas river basins. The apparent absence of antithetic and transfer faults in combination with the general direction of the rivers channel which is parallel to the major faults has as a result the river to have maintained its flow direction [10], although morphological processes have a major impact to the study area As a result, the past, present and future evolution is important as it's directly connected to already existent hazards.

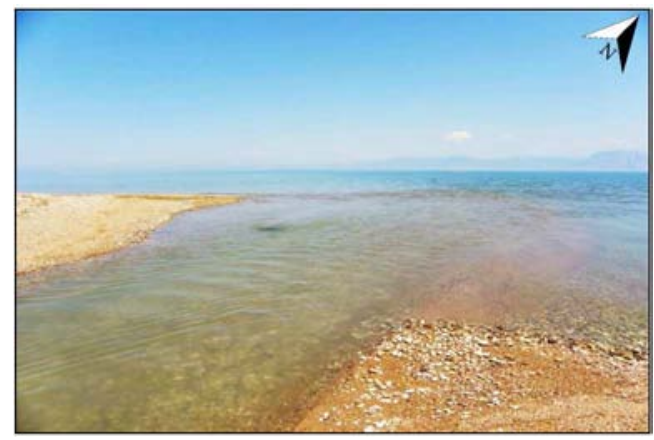

Figure 2. Peiros river estuary characterized by yellow to brown, fine to coarse gravelly sand with occasional lenses of coarser particles.

\section{Results and Discussion}

River channel morphology is the result of liquid and solid flow transiting the hydrological system, associated with the catchment features and human influences [3]. These control variables may induce channel adjustments at a certain time scale and create significant risks in the affected areas. For example, lateral and vertical river bank adjustments are noticed at a time scale inferior to 5 years. Human activity is an important control factor both for the processes of sediment generation, transfer and accumulation and for the channel dynamics. At the same time, these processes are responsible on short and long run for the alteration of the river channels, which entail negative environmental and socio-economic consequences. The spatial and temporal variability of sediment transport is controlled by a combination of different variables, including the natural features of the catchments and human activity [3].

The middle and lower Peiros's river channel parts are located at an altitude lower than $600 \mathrm{~m}$. and constitute about $75 \%$ of the total channel length. The evolution of Peiros river mirrors the horizontal dynamics of the channel through lateral cutting, as well as the rivers tendency to acquire the graded condition. River gradient, liquid and solid flow, tectonics, human impact and some local environmental conditions may influence the channels formation and dynamics.

During the Early Holocene, like other parts of the world, the study area underwent a rapid change of climate which became temperate, marked by a widespread development of thick fluvial sedimentation which consequently led to the rivers migration. The new environmental conditions drastically reduced slope degradation processes and related aggradations of riverbeds which was replaced by major depositional processes [13]. The aforementioned delta progradations and fluctuations of the river channels shape and placement, has consisted a significant source of risk in the area.

The construction of Peiros-Parapeiros dam (Valmantouras), which started in 2006, led to a significant reduction of sediment supply. These factors were also aided by illegal sand and gravel extraction from the rivers channel to be used as inert. These factors of fluvial change were assisted by the construction of several transversal terraces throughout the river's course (Figures 3-4) that were used to stabilize the bottom of the river but it also restricted the sediment supply. That led to a general aggradation trend, combined with lateral movement of the bank as a result of the erosional nature of the river channel. It is deduced that major metamorphosis of the braided channel is taking place, something that is reflected in the analysis made and shown in Figures 5-11.

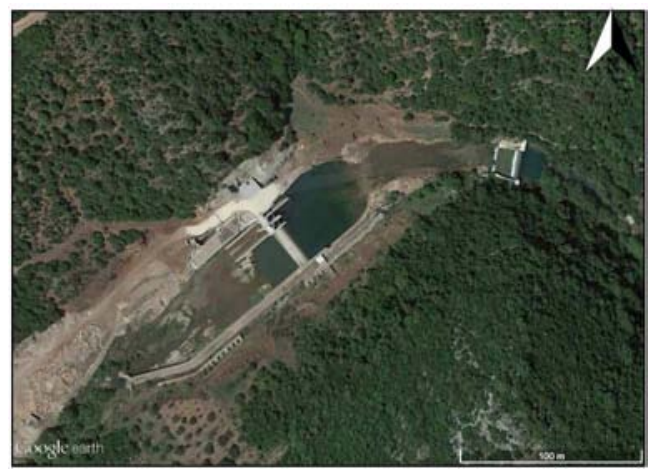

Figure 3. View of the constructed dam (Google Earth Pro/ Terra Metrics).

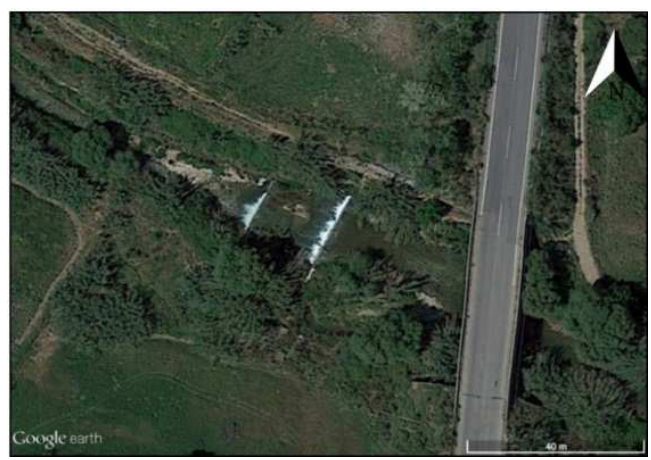

Figure 4. View of the transversal terraces after the dam (Google Earth Pro/ Terra Metrics).

Lateral erosion of the river channel appears to be taking place, that leads to its migration of over $13 \mathrm{~m}$. close to the estuary between 2002 and 2015 (Figure 5).

The coast during the same period, is calculated to have 
retreated 4-22 $\mathrm{m}$. with the maximum retreat taking place on and close to the estuary. This corresponds to the dam's construction and the restriction of water and sediment flow. The reaction of the river, after the dam's construction is better showed on Figure 6 with a maximum retreat of $35 \mathrm{~m}$. that is later decreased to $22 \mathrm{~m}$ (Figure 5).

Additionally, the river's mouth also appears to be shrinked.

The lateral migration of the river's mouth is a factor that contributes to the major morphological change of the river and the study area in general. Both ends of the river's mouth show a trend of eastward migration, with the movement rate of the western part of the mouth being higher. The overall migration is calculated to be around $10 \mathrm{~m}$. between 2002 and 2015. This uneven lateral migration led to the estuary's shrinkage of around $5 \mathrm{~m}$. The maximum migration, observed locally on the middle flow part of the river, studied between 2007 and 2014, reaches $70 \mathrm{~m}$. while channel movements of $8-35 \mathrm{~m}$. are usual (Figures 7-11).

Furthermore, the rivers channel shows a general tendency for shrinkage, as well as a slight migration to the North-Northeast, corresponding to local tectonics and especially the major strike slip fault in the area. Generally, rare signs of stream offsets are observed, even if the tectonism in the area is considered to be active.

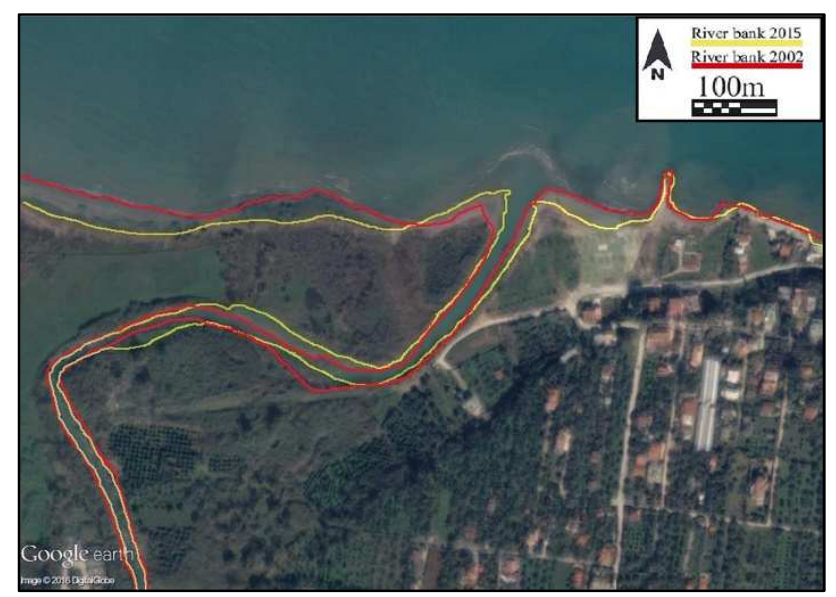

Figure 5. Partial view of Peiros river alluvial fan and estuary migration through years 2002-2015 (Basemap: Google Earth Pro/ Terra Metrics).

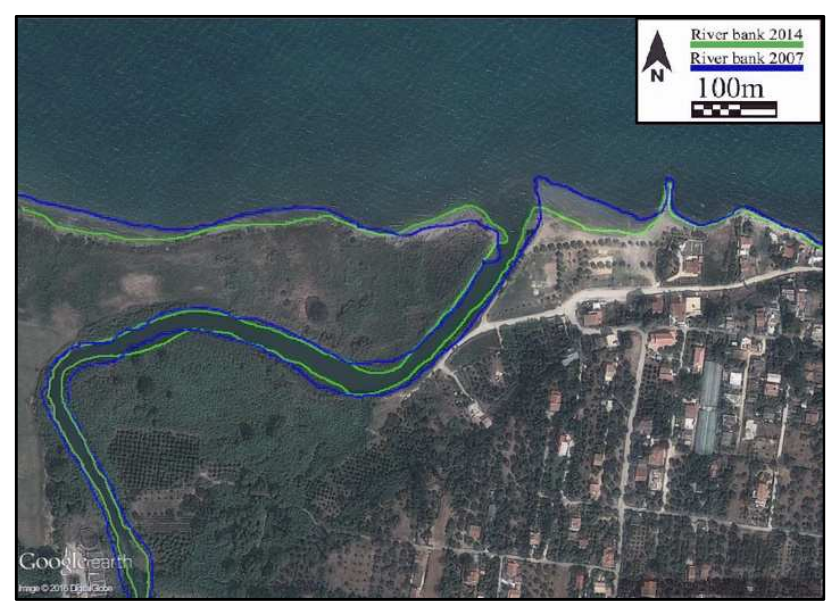

Figure 6. Partial view of Peiros river alluvial fan and estuary migration through years 2007-2014 (Basemap: Google Earth Pro/ Terra Metrics).

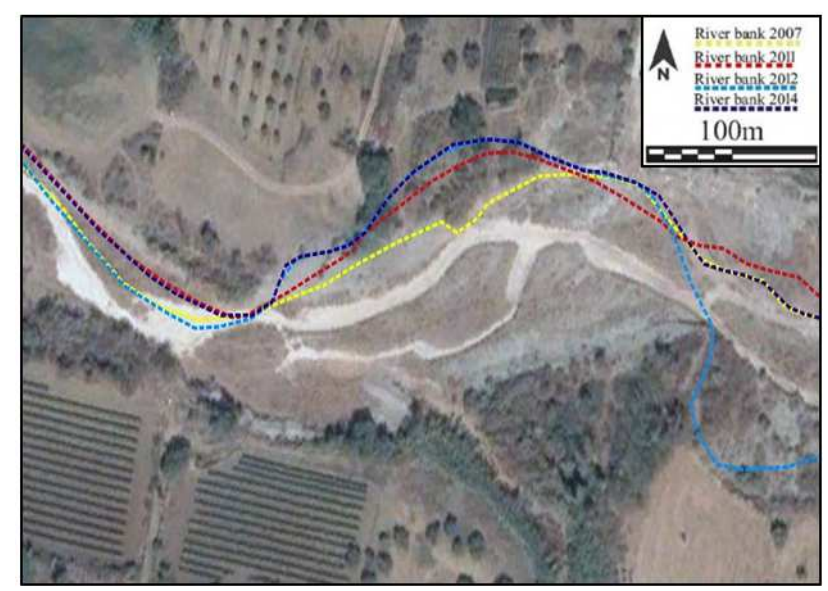

Figure 7. Partial views of Peiros's river channel migration through years 2007-2014. Basemap: Google Earth Pro/ Terra Metrics.

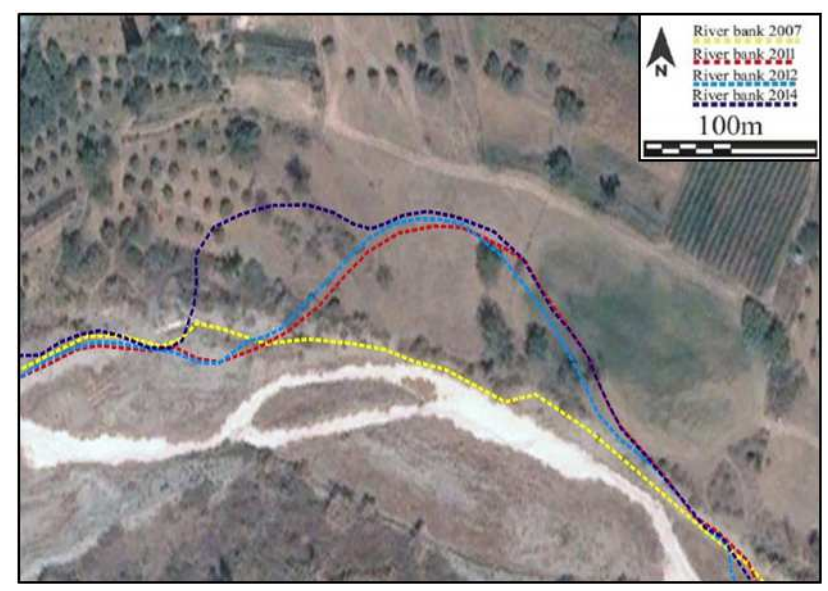

Figure 8. Partial views of Peiros's river channel migration through years 2007-2014. Basemap: Google Earth Pro/ Terra Metrics.

\section{Conclusions}

Fluvial dynamics is a complex topic with various factors contributing to the current studied geomorphological result.

River channels are not static; they are dynamic systems as they move through lateral migration of meanders as well as through avulsion and channel transfer, constantly responding to natural and human-induced changes in downstream water and sediment movement.

The research showed that close to the coast, Peiros's river channel migration is calculated to be over $13 \mathrm{~m}$. at places, studied in a period of 13 years (2002-2015), while the river bank appears to be locally shrinked. The migration shows a general slight tendency to move towards a N/NE direction, corresponding to the local tectonics of the area and especially the active strike slip fault, while stream offsets as a result of tectonic action are rare.

Orthophotographs and satellite image comparisons, along with field studies showed channel migration, as well as significantly less fill, placed along the channel, something that led to the shrinking of the river channel. The coastal retreat was calculated to be $4-22 \mathrm{~m}$ to the south, between 2002 and 2015 with the maximum retreat taking place on and close to the estuary. Additionally, the 
morphology of the river's mouth through the years has changed and appears to be also shrinked around $5 \mathrm{~m}$. in this period of 13 years.

Human activity, in the form of the construction of transversal terraces and the dam, which controls the water flow through the spillway, were aggravating factors to the major channel migration observed in the studied period.

The channel migration of the middle flow part of Peiros river, studied in a period of 7 years (2007-2014), was calculated to be on a range of $4-70 \mathrm{~m}$. Usually, it is found to be between 8-35 $\mathrm{m}$ on meander apexes where the erosional forces are higher (Figures 9-11). This movement altered the sedimentary status quo of the river's channel and reinvigorated the erosional processes, with less sedimentary material being carried by the water mass, that had as a result to the major movements that were herein examined. The impact these movements had, is also of great importance as, except property boundary problems and loss of property, it also made the area vulnerable to flush flood events, as the rushing water could pass the lowered levees and point bars and easily flood neighboring areas. Additionally, structures close to the coastal area are now threatened by the sea as they are exposed to higher risk because of the coastal retreat.

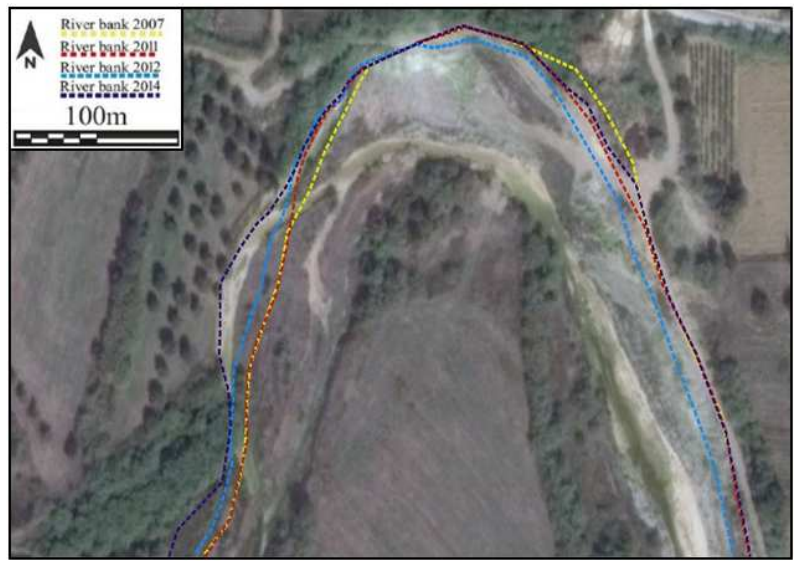

Figure 9. Partial view of Peiros's river channel showing migration and channel shrinkage through years 2007-2014.

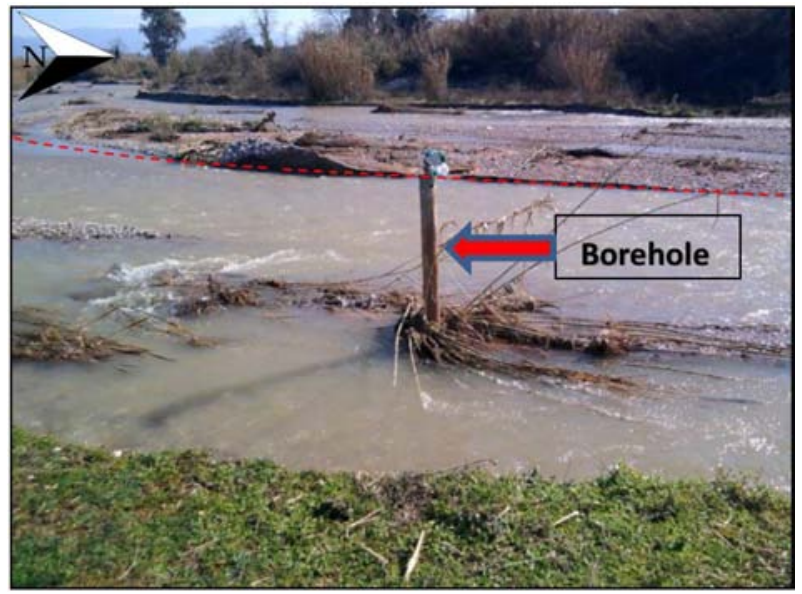

Figure 10. Partial view of Peiros's river channel showing an irrigation borehole, drilled before the channel'sl migration. Older bank location (2007) marked in red dotted line. The migration locally is estimated to be $35 \mathrm{~m}$.

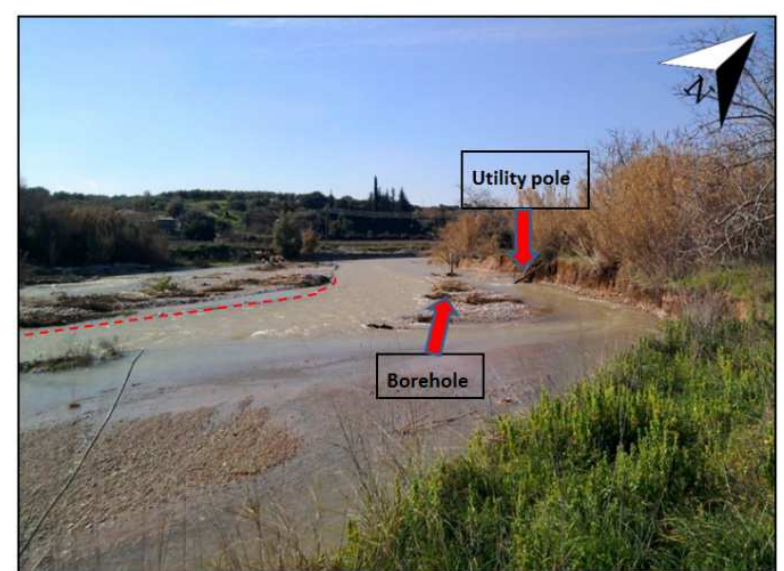

Figure 11. Partial view of Peiros's river channel showing the migration of the rivers channel. Older bank location (2007) marked in red dotted line. A utility pole is seen to be collapsed in the river channel due to bank weathering.

Finally, no remediation measures have been taken so far, except from the installation of rip-rap of limited length and one groin, in an attempt to slow down the coastal retreat and diminish wave action.

It can be deduced that this close relationship of man with the environment, constitutes a necessary tool to understand the landscape evolution which will help us to better assess and act on present and future risks.

\section{References}

[1] P. P. C. Aucelli, P. Fortini, C. M. Rosskopf, V. Scorpio, and V. Viscosi, Recent channel adjustments and riparian vegetation response: Some examples from Molise (Italy). Geografia Fisica e Dinamica Quaternaria, 34, 161-173, 2011.

[2] M. Colorti, and P. Pieruccini, Fluvial architecture and dynamics in rising mountain chains and related basins; tectonic, climatic influence and human impact: The FLAG-SEQS (Fluvial Archive Group-Subcommission for European Quaternary Stratigraphy) Siena Meeting. Quaternary International, 189, $1-4,2008$.

[3] L. Zaharia, F. Grecu, G. I. Toroimac, and G. Neculau, Sediment transport and river channel dynamics in Romania - Variability and control factors. In Sediment Transport in Aquatic Environments, Dr. Andrew Manning (Ed.), InTech, 2011.

[4] E. Zelilidis, Drainage evolution in a rifted basin, Corinth graben, Greece. Geomorphology, 35, 69-85, 2000.

[5] J. Dufaure, M. H. Kadjer, B. Keraudren, J. L. Mercier, J. Sauvage, and Sebrier, M., Les deformations plio-pleistocene autour du golf de Corinthe, C. r. somn. Soc. Geol. Fr., 18-20, 1975.

[6] D. J. Piper, and A. Panagos, Marine Geology of the Gulf of Patras, Thalassographica, 3, 5-20, 1979.

[7] A. Zelilidis, I. Koukouvelas, and T. Doutsos, Neogene paleostress changes behind the forearc fold belt in the Patraikos Gulf area, Western Greece. Neues Jahrbuch für Geologie und Paläontologie, 5, 311-325, 1988.

[8] D. J. W. Piper, A. G. Panagos, and N. Kontopoulos, Coastal processes and mporphology, Gulf of Patras, Greece, Zeitschrift für Geomorphologie, 26 (3), 365-374, 1982. 
[9] D. J. J van Hinsbergen, W. J. Zachariasse, M. J. R. Wortel, and J. E. Meulenkamp, Underthrusting and exhumation: A comparison between the External Hellenides and the "hot" Cycladic and "cold" South Aegean core complexes (Greece), Tectonics, 24, 1-19, 2005.

[10] A. Zelilidis, Drainage evolution in a rifted basin, Corinth graben, Greece. Geomorphology, 35, 69-85, 2000.

[11] D. Frydas, Biostratigraphische Untersuchungen aus dem Neogen der NW- und W-Peloponnes, Griechenland. Neues Jahrbuch für Geologie und Paläontologie, 6, 321-344, 1989.
[12] N. Flotte', D. Sore, C. Müller and J. Tensi, Along strike changes in the structural evolution over a brittle detachment fault: Example of the Pleistocene Corinth-Patras rift (Greece). Tectonophysics, 403, 77-94, 2005.

[13] G. Alevizos, and L. Stamatopoulos, Landscape geomorphological evolution and coastal changes: A case study of coastal evolution in the Western Patraikos Gulf area, Western Greece, Bulletin of the Geological Society of Greece, 11, 415-423, 2016. 